\title{
Multiplatform Distributed Architecture of Learning Content Management System
}

\author{
Nizam Omar, Pollyana Notargiacomo Mustaro \\ Ismar Frango Silveira, and Daniel Arndt Alves \\ Universidade Presbiteriana Mackenzie - Sao Paulo, SP, Brazil \\ omar@mackenzie.br polly@mackenzie.br \\ ismar@mackenzie.br progdan@mackenzie.com.br
}

\begin{abstract}
Learning objects are constructed and used by a community during an undefined period of time and formatted as digital entities on diverse document types to be used, reused or referenced during a technology-mediated learning process. A Learning Content Management System (LCMS) is needed to their storage and retrieval.

Electronic document management, data warehouse and data mining techniques will be presented. Effective management of a really big repository of Learning Objects by a community on a large network needs a system that facilitates the right access to the right document by its content and not only by title, author or other usual indexing fields. Learning Objects must be found by their full content and indexed and customized according to each user or user groups' necessities.

The main indexing and retrieving techniques will be discussed and a solution will be presented. Different learning objects can be stored on a common repository and duplication must be avoided. To fulfill this requirement the system needs to implement smart strategies that can be constructed based on AI techniques.

Considering the diversity of users, machines and operating systems, the LCMS must be platform independent and manage portable resources, thus giving access to any user from any machine. LCMS must be scalable enough in order to avoid abrupt changes from small applications to big ones, without losing performance.
\end{abstract}

A multiplatform distributed LCMS architecture is presented, and it is composed by: Interface server, data server, parser server, index server and repository server. These servers can run on a single machine or on a cluster of machines according to the needs of the application.

Material published as part of these proceedings, either on-line or in print, is copyrighted by Informing Science. Permission to make digital or paper copy of part or all of these works for personal or classroom use is granted without fee provided that the copies are not made or distributed for profit or commercial advantage AND that copies 1) bear this notice in full and 2) give the full citation on the first page. It is permissible to abstract these works so long as credit is given. To copy in all other cases or to republish or to post on a server or to redistribute to lists requires specific permission from the publisher at Publisher@InformingScience.org 